\title{
Bone Morphogenetic Protein 7
}

National Cancer Institute

\section{Source}

National Cancer Institute. Bone Morphogenetic Protein 7. NCI Thesaurus. Code C21358.

Bone morphogenetic protein 7 (431 aa, $\sim 49 \mathrm{kDa}$ ) is encoded by the human BMP7 gene.

This protein plays a role in both cellular differentiation and organogenesis. 